American Journal of Applied Sciences 6 (7): 1331-1340, 2009

ISSN 1546-9239

(C) 2009 Science Publications

\title{
Molecular Characterization of a Phytoplasma Associated with Coconut Yellow Decline (CYD) in Malaysia
}

\author{
${ }^{1}$ N. Nejat, ${ }^{1}$ K. Sijam, ${ }^{2}$ S.N.A. Abdullah, ${ }^{1}$ G. Vadamalai and ${ }^{3}$ M. Dickinson \\ ${ }^{1}$ Department of Plant Protection, Faculty of Agriculture, \\ University Putra Malaysia, 43400, Malaysia \\ ${ }^{2}$ Department of Agriculture Technology, Faculty of Agriculture, \\ University Putra Malaysia, 43400, Malaysia \\ ${ }^{3}$ School of Biosciences, University of Nottingham, Sutton Bonington Campus, \\ Loughborough, LE12 5RD, UK
}

\begin{abstract}
Problem statement: Molecular methods have been used to detect phytoplasma in Malayan Red Dwarf (MRD) ecotype of coconut for the first time in Malaysia. Detect phytoplasma from coconut showing yellowing symptoms by nested PCR and Classify phytoplasma associated with disease of coconut palms, based on analysis of 16S rRNA gene operon sequences and virtual RFLP. Approach: Twenty MRD symptomatic palms were tested. Leaf spear, inflorescence and wood shavings from trunks of coconut palms showing yellowing symptoms were harvested from Serdang located in Selangor state. PCR assays and sequence analysis were carried out. Results: Nested PCR with primer pairs R16F2n/R16R2 and fU5/rU3 resulted in amplification of products of approximately $1.2 \mathrm{~kb}$ and $890 \mathrm{bp}$ respectively, from 8 out of $20 \mathrm{MRD}$ symptomatic palms tested. Sequence analysis of the 16S rDNA PCR products determined that the phytoplasma strain associated with Coconut Yellow Decline (CYD) in MRD ecotype belongs to the 'Candidatus Phytoplasma cynodontis' (16SrXIV) group of phytoplasmas. In addition, nested R16F2n/R16R2 PCR products from 6 spear leaves and 2 inflorescences from MRD palms showed high sequence similarity to the 16S rRNA gene from coconut chloroplasts, with a similar size (approximately $1.3 \mathrm{~kb}$ ) and a further 5 R16F2n/R16R2 PCR products from MRD inflorescences showed high sequence similarities to Bacillus spp. 16S rRNA gene sequences. Conclusion: These results indicate that sequencing is a reliable method for the detection. Furthermore, trunk borings are the most reliable source of DNA for phytoplasma detection in coconuts using 16S rRNA gene primers, since there is less co-amplification of PCR products from other organisms when compared to spear leaves and inflorescences, nor from the spear leaves and inflorescences of MRD palms when primers fU5/rU3 were used in nested PCR.
\end{abstract}

Key words: Coconut palm, phytoplasma, nested PCR, cloning, sequencing

\section{INTRODUCTION}

Coconut palm (Cocos nucifera L.) is a versatile tree, popularly know as 'King of Palms' and 'Kalpavriksha', which translates as "tree that gives all that is necessary for living." Considered the most useful tree in the world, the coconut palm not only provides sustainable income to millions who are directly and indirectly dependant on it, but also provides highly nutritious food, drink, clothing, shelter, heirloom history, financial security, alleviate poverty and export earnings ${ }^{[48]}$.

Many historians believe that the origin of coconut was in the Asia- Pacific region, more specifically the Malayan Archipelago ${ }^{[32]}$. The large number of coconut palms shows general yellowing symptoms of fronds. General yellowing and decline of plants are often considered as the symptoms of the presence of phytoplasmas, which are the causal agents of plants yellows diseases ${ }^{[23]}$ and the symptoms of diseased palms show similarities to coconut lethal yellowing. Lethal Yellowing (LY) caused by phytoplasmas is a highly destructive disease on coconut and has been reported in the Caribbean, Florida and Mexico ${ }^{[38-40]}$. The first symptoms are yellowing of fronds followed by blackening of emerging inflorescences, premature nutfall and usually nut production effectively stops. Similar lethal-yellowing-like diseases caused by phytoplasmas have also devastated palms in both west and east Africa ${ }^{[17]}$.

Corresponding Authors: K. Sijam and N. Nejat, Department of Plant Protection, Faculty of Agriculture, University Putra Malaysia, 43400, Malaysia Tel: +60 389467243 Facsimile: +60 386560698 
The phytoplasmas are wall-less prokaryotes that live as obligate parasites and are amongst the smallest and simplest self-replicating organisms known. Phytoplasmas normally inhabit the phloem of plants at low concentrations and have an uneven distribution in woody plants especially in monocots. These characteristics make their detection and identification difficult ${ }^{[46]}$, but molecular diagnostics and in particular the use of PCR, have been developed as the main tools for confirming the presence of phytoplasmas and for assigning them to taxonomic groups ${ }^{[16,1,53]}$. On the basis of disease symptoms, the disease in Malaysia has been named coconut yellow decline and a preliminary report on this disease has been published ${ }^{[34,35]}$. Coconut Yellow Decline (CYD) phytoplasma belongs to the 16SrXIV Bermuda grass white leaf group is widespread disease in many coconut-growing areas of Malaysia and wherever the Malayan coconut ecotypes are grown. This current study was undertaken to determine the etiology of coconut yellow decline in Malaysia in greater detail.

\section{MATERIALS AND METHODS}

Sources of healthy and diseased coconut palms: Tissue samples were collected from 20 Malayan Red Dwarf (MRD) coconut palms showing symptoms of the disease referred to as Coconut Yellow Decline (CYD). Coconut palm samples were obtained from disease areas in Selangor State. Symptomless palms from disease-free areas of Kuala Selangor were selected as negative controls. Spear leaves, inflorescences and wood shavings from trunks of MRD ecotypes were used for the preparation of DNA. Wood shavings were obtained by boring a hole $15 \mathrm{~cm}$ in length and $1 \mathrm{~cm}$ diameter into the palm trunk using a hand drill and were collected into polyethylene plastic bags and stored on ice for transport back to the laboratory. Samples from symptomless tall coconuts were also collected by this method.

Samples of 16SrII chickpea phyllody, 16SrII crotalaria saltiana phyllody, 16SrIV Cape St Paul wilt, $16 \mathrm{SrVI}$ brinjal little leaf and $16 \mathrm{SrXI}$ napier grass stunt from the University of Nottingham phytoplasma collection $^{[17]}$ and 16SrI aster yellows and 16SrXIV bermuda grass white leaf form the University Putra Malaysia Campus, were used for comparative purposes.

DNA extraction: DNA was extracted from $3 \mathrm{~g}$ of MRD spear leaves and inflorescences employing a phytoplasma enrichment procedure as described by Ahrens and Seemüller ${ }^{[1]}$ with some modifications. The MRD tissue was homogenized in $12 \mathrm{~mL}$ ice-cold grinding buffer (125 potassium phosphate, $30 \mathrm{mM}$ ascorbic acid, 10 sucrose, 0.15 bovine serum albumin, $2 \%$ polyvinylpyrrolidone, $\mathrm{pH}$ 7.6) in a polyethylene plastic bag using a hammer. The slurry was then collected and centrifuged for $5 \mathrm{~min}$ at $1100 \times \mathrm{g}$ and the resultant supernatant was re-centrifuged at $12000 \times \mathrm{g}$ for $40 \mathrm{~min}$ at $4^{\circ} \mathrm{C}$. The resultant pellet was resuspended in $1.5 \mathrm{~mL}$ CTAB buffer $(2 \% \mathrm{w} / \mathrm{v}$ cetyltrimethylammonium bromide, $1.4 \mathrm{M} \mathrm{NaCl}, 0.2 \%$ 2-mercaptoethanol, $20 \mathrm{mM}$ EDTA, $100 \mathrm{mM}$ Tris-Base, 2\% polyvinylpyrrolydone, $\mathrm{pH} \mathrm{8.0)}$ and incubated at $65^{\circ} \mathrm{C}$ for $30 \mathrm{~min}$. An equal volume of chloroform-isoamyl alcohol (24:1) was added to the lysis, vortexed for $1 \mathrm{~min}$ and centrifuged at $12000 \times \mathrm{g}$ for $10 \mathrm{~min}$. This step was repeated twice. DNA was precipitated with a two-third volume of icecold isopropanol, incubated at $-20^{\circ} \mathrm{C}$ for $20 \mathrm{~min}$ and then centrifuged at $12000 \times \mathrm{g}$ for $15 \mathrm{~min}$. The pellet was washed with ice-cold $70 \%$ ethanol, dried at room temperature and dissolved in $100 \mu \mathrm{L}$ of ultrapure sterile water by incubation for $1 \mathrm{~h}$ at room temperature.

Total nucleic acid was also extracted from wood shavings of MRD and control coconut palms using the procedure of Zhang et al. ${ }^{[55]} 0.2 \mathrm{~g}$ of wood shaving tissue was frozen in liquid nitrogen in a mortar and pestle. $800 \mu \mathrm{L}$ of CTAB buffer preheated at 65 was added to the fine powder and was incubated at $65^{\circ} \mathrm{C}$ for $30 \mathrm{~min}$. The lysate was extracted with $2 / 3$ volume of chloroform-isoamyl alcohol and centrifuged at $13000 \times \mathrm{g}$ for $10 \mathrm{~min}$. This step was repeated twice. An equal volume of ice-cold isopropanol was added to the aqueous phase, incubated at $-20^{\circ} \mathrm{C}$ for $15 \mathrm{~min}$ and then centrifuged for $15 \mathrm{~min}$ in $14000 \times \mathrm{g}$. Pellets were rinsed in $1 / 3$ volume of $70 \%$ ethanol, air dried and dissolved in $50 \mu \mathrm{L}$ ultrapure water.

Primers and Polymerase Chain Reaction (PCR) analysis: DNA from symptomatic and asymptomatic MRD coconut samples wsas amplified using direct and nested PCR. The phytoplasma universal primer pairs P1 (5'-AAG AGT TTG ATC CTG GCT CAG GAT T-3')

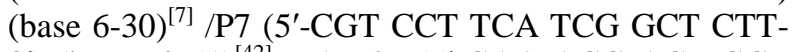
$\left.3^{\prime}\right)(\text { base } 68-51)^{[42]}$, R16F2n (5'-GAA ACG ACT GCT AAG ACT GG-3') (base 149- 168) ${ }^{[11]} / \mathrm{R} 16 \mathrm{R} 2$ (5'-TGA CGG GCG GTG TGT ACA AAC CCC G-3') (base $1397-1373)^{[26]}$ and fU5 (5'-CGG CAA TGG AGG AAA CT-3') (base 369-386)/rU3 (5'-TTC AGC TAC TCT TTG TAA CA-3') (base 1251-1231) ${ }^{[28]}$ derived from conserved regions of the 16S rRNA gene sequence were used to amplify phytoplasma ribosomal DNA. Universal primer pair P1/P7 amplify a $1.8 \mathrm{~kb}$ fragment that encompasses the entire 16S rRNA gene, the 16S-23S intergenic spacer region and the beginning of the $23 \mathrm{~S}$ rRNA gene. Primer pairs R16F2n/R16R2 and fU5/rU3 amplify 1239 (137-1376) and 880 (356-1232) bp fragments respectively of the $16 \mathrm{~S}$ rRNA gene internal to the P1/P7 priming sites. PCR assays were performed in 20 volumes containing 1 of DNA template, 1 of each primer (10 pmol), 0.4 of $10 \mathrm{mM} \mathrm{dNTP}, 0.6$ of $25 \mathrm{mM}$ 
$\mathrm{MgCl}_{2}, 2$ of $10 \mathrm{X}$ Taq polymerase buffer and $0.3 \mu \mathrm{L}$ (0.5 units) Taq DNA polymerase (Fermentas Inc.).

First round amplifications with $\mathrm{P} 1 / \mathrm{P} 7$ primers were performed in an iCycler (BioRad) thermocycler using $1 \mathrm{~min}$ ( $2 \mathrm{~min}$ for an initial denaturation) at 94, 2 min at $55^{\circ} \mathrm{C}$ and $3 \mathrm{~min}$ at $72^{\circ} \mathrm{C}$ for 35 cycles and a final extension at $72^{\circ} \mathrm{C}$ for $10 \mathrm{~min}^{[26]}$. one $\mu \mathrm{L}$ of the P1/P7 reaction product was used as the template in nested PCR using primer pairs R16F2n/R16R2 or fU5/rU3 under the same conditions as described for P1/P7. Aliquots of $10 \mu \mathrm{L}$ of each final reaction mixture were analyzed by $1 \%$ agarose gel electrophoresis using TBE (90mM Tris-borate, 2mM EDTA) as the running buffer. Gels were stained in ethidium bromide, visualized by UV transillumination and photographed.

Cloning and sequencing of PCR products: The R16F2n/R16R2 primed rDNA PCR products from CYD-infected Malayan Red Dwarf palms were purified from agarose gels using the Qiaquick gel extraction kit (Qiagen). They were cloned using a PCR cloning kit by ligation into the pCR2.1 vector and transformed into TOP10 E. coli competent cells by heat shock following the manufacturer's instructions (Invitrogen, Carlsbad, CA, USA). Plasmids were prepared from transformed bacterial colonies and extracted using the Qiagen plasmid Miniprep kit and sequenced commercially by automated sequencing machines (Medigene Sdn Bhd.).

Sequence analysis: Sequence editing and analysis was performed using the DNAsis programs. The phylogenetic analysis of $16 \mathrm{~S}$ rRNA gene sequences isolated from CYD phytoplasmas in this study and other known phytoplasmas obtained from the Basic Local Alignment Search Tool (BLAST) searches ${ }^{[2]}$ at the National Center for Biotechnological Information (NCBI) and Acholeplasma laidlawii (Table 1) as an outgroup species, were performed using the program CLUSTAL W (Version 3.1) ${ }^{[49]}$. Phylogenetic and molecular evolutionary analyses were performed with $M E G A$ version 3.1 software $^{[22]}$ using the NeighborJoining method with default values and 1000 replications for bootstrap analysis.

Table 1: Phytoplasma 16S rDNA sequences used as references in this study

\begin{tabular}{|c|c|c|c|c|}
\hline Acronym & Phytoplasma or association disease & 16S rRNA group & Gen Bank accession no. & Reference \\
\hline Ca.P. asteris & Candidatus phytoplasma asteries & $16 \mathrm{SrI}$ & M30790 & Lee et $_{\text {al }}^{[25]}$ \\
\hline Ca. P. aurantifolia & Candidatus phytoplasma aurantifolia & $16 \mathrm{SrII}$ & U15442 & Zreik et al. ${ }^{[56]}$ \\
\hline WX & Western X & $16 \mathrm{SrIII}$ & L04682 & 1999 (Gen Bank submission) \\
\hline CLY & Coconut lethal yellowing phytoplasma & $16 \mathrm{SrIV}$ & AF498307 & Harrison et al. ${ }^{[13]}$ \\
\hline Ca.P. ulmi & Candidatus Phytoplasma ulmi & $16 \mathrm{SrV}$ & AY197655 & Lee et $a l .^{[27]}$ \\
\hline Ca.P. trifolii & Candidatus Phytopolasma trifolii & $16 \mathrm{SrVI}$ & AY390261 & Hiruki and Wang ${ }^{[15]}$, \\
\hline Ca. P. fraxini & Candidatus Phytoplasma fraxini & 16SVII & AF092209 & Griffiths et al..$^{[10]}$ \\
\hline $\begin{array}{l}\text { LWB } \\
\text { submission)h }\end{array}$ & Loofah witches-broom phytoplasma & $16 \mathrm{SrVIII}$ & AF353090 & $2001 \quad$ (Gen \\
\hline Ca. $P$. phoenicium & Candidatus phytoplasma Phoenicium & 16SrIX & AF515636 & Verdin et al. ${ }^{[51]}$ \\
\hline Ca.P. mali & Candidatus phytoplasma mali & $16 \mathrm{SrX}$ & AJ542541 & Seemüller and Schneider ${ }^{[45]}$ \\
\hline Ca.P. oryzae & Candidatus phytoplasma oryzae & $16 \mathrm{SrXI}$ & $\mathrm{AB} 052873$ & Jung et al..$^{[21]}$ \\
\hline Ca. P. australiense & Candidatus phytoplasma australiense & $16 \mathrm{SrXII}$ & L76865 & Davis et al. ${ }^{[6]}$ \\
\hline Ca.P. japonicum & Candidatus phytoplasma japonicum & 16SrXII & AB010425 & Sawayanagi et al. ${ }^{[41]}$ \\
\hline MPV & Mexican periwinkle virescence & $16 \mathrm{SrXIII}$ & AF248960 & 2000 (Gen Bank submission) \\
\hline Ca.P. cynodontis & Candidatus phytoplasma cynodontis & 16SrXIV & AJ550984 & Marcone et al..$^{[27]}$ \\
\hline MBGWL & Malaysia bermuda grass white leaf & 16SrXIV & EU294011 & 2007 (Gen Bank submission) \\
\hline TBGWL & Thailand bermuda grass white leaf & 16SrXIV & AF248961 & 2000 (Gen Bank submission) \\
\hline ITBGWL & Italy bermuda grass white leaf & 16SrXIV & AJ550984 & Marcone et al..$^{[30]}$ \\
\hline INBGWL & India bermuda grass white leaf & 16SrXIV & EU032485 & Snehi et al. ${ }^{[47]}$ \\
\hline IRBGWL & Iran bermuda grass white leaf & 16SrXIV & EF444485 & 2007 (Gen Bank submission) \\
\hline CYDMRD & Coconut yellow decline strain MRD & 16SrXIV & EU328159 & In this study \\
\hline CYDMT & Coconut yellow decline strain Malayan Tall & 16SrXIV & EU636906 & 2007 (Gen Bank submission) \\
\hline Ca.P. brasiliense & Candidatus phytoplasma brasiliense & $16 \mathrm{SrXV}$ & AF147708 & Montano et $a l_{.}^{[33]}$ \\
\hline Ca. P. graminis & Candidatus phytoplasma graminis & 16SrXVI & AY725228 & Arocha et al..$^{[3]}$ \\
\hline Ca.P. Caricae & Candidatus phytoplasma caricae & 16SrXVII & AY725234 & Arocha et al. ${ }^{[3]}$ \\
\hline Ca.P. Americanum & Candidatus phytoplasma americanum & 16SrXVIII & DQ174122 & Lee et $a l .^{[24]}$ \\
\hline Ca.P. castaneae & Candidatus phytoplasma castaneae & 16SrXIX & AB054986 & Jung et al..$^{[20]}$ \\
\hline Ca. P. rhamni & Candidatus phytoplasma rhamni & $16 \mathrm{SrXX}$ & X76431 & Marcone et al. ${ }^{[29]}$ \\
\hline Ca.P.pini & Candidatus phytoplasma pini & $16 \mathrm{SrXXI}$ & AJ632155 & Schneider et al. $_{.}^{[43]}$ \\
\hline$P h . s p$ & Phytoplasma sp. strain LDN & 16SrXXII & Y14175 & Tymon et al..$^{[50]}$ \\
\hline BVGYP & Buckland valley grapevine yellows phytoplasma & $16 \mathrm{SrXXIII}$ & AY083605 & Constable et al. ${ }^{[5]}$ \\
\hline SBSP & Sorghum bunchy shoot phytoplasma & 16SrXXIV & AF509322 & Blanche et al. ${ }^{[4]}$ \\
\hline WTWBP & Weeping tea witches'-broom phytoplasma & $16 \mathrm{SrXXV}$ & AF521672 & 2002 (Gen Bank submission) \\
\hline $\mathrm{ScP} 1$ & Sugar cane phytoplasma D3T1 & 16SrXXVI & AJ539179 & 2003 (Gen Bank submission) \\
\hline $\mathrm{ScP} 2$ & Sugar cane phytoplasma D3T2 & 16SrXXVII & AJ539180 & 2003 (Gen Bank submission) \\
\hline DP & Derbid phytoplasma & 16SrXXVIII & AY744945 & 2004 (Gen Bank submission) \\
\hline A. laidlawii & Acholeplasma laidlawii & - & M23932 & Weisburg et al..$^{[54]}$ \\
\hline
\end{tabular}


In silico restriction enzyme digestions and virtual gel plotting: The MRD CYD phytoplasma sequence was obtained in this study and $16 \mathrm{~S}$ rRNA gene R16F2n/R16R2 fragments from Ca. P. asteris (16SrI) [M30790], Coconut lethal yellowing (16SrIV) [AF498307], Ca. P. oryzae (16SRXI) [AB052873], Ca. $P$. cynodontis (16SrXIV) [AJ550984] and Lethal decline Nigeria (16SrXXII) [Y14175] were exported to the in silico restriction analysis and virtual gel plotting program pDRAW32, developed by AcaClone Software (http://www.acaclone.com). Each aligned DNA fragment was digested in silico with AluI, HhaI, Hinfl, Sau3AI (MboI), MseI, RsaI and TaqI restriction enzymes. After in silico restriction digestion, a virtual $3.0 \%$ agarose gel electrophoresis image with minimum $50 \mathrm{bp}$ was plotted automatically to the computer screen.

\section{RESULTS}

Disease symptoms: The initial symptom observed in Malayan red dwarf coconut palms was yellowing of the coconut foliage. In addition, the lower canopy foliage turned light yellow and eventually light-brown and the symptoms spread rapidly to the younger leaves. Severe chlorosis of the emerging spear leaves, inflorescence necrosis, premature nut fall and gradual collapse of fronds also occurred and there was terminal rot of the growing point of immature palms and palms generally died within 5 months of initial symptom appearance.

Detection of phytoplasma DNA in coconut palms by PCR: No amplification products were visible after the first round 35 cycles of amplification from the DNA of CYD infected samples from trunk borings or any other tissues. However, PCR products of approximately 1250 and 900 bp were amplified from 8 of 20 symptomatic MRD DNA samples with primers R16F2n/R16R2 or fU5/rU3 respectively, after PCR products from the first round were subjected to nested PCR (Fig. 1a and b). A PCR product of approximately $1.3 \mathrm{~kb}$ was also amplified in nested PCR using primers R16F2n/R16R2 from the spear leaves of 4 symptomatic and 2 of the apparently healthy MRD coconut palms (Fig. 2) and from 2 (one from diseased and one from healthy) inflorescences (results not shown). In addition, a PCR product of approximately $1250 \mathrm{bp}$ was amplified from a further 5 symptomatic MRD inflorescences. No amplification products were produced from trunk borings of asymptomatic MRD palms using any primer combinations, nor from the spear leaves and inflorescences of MRD palms when primers fU5/rU3 were used in nested PCR.
Sequence analysis of amplified products: PCR products obtained from the MRD palms were cloned into the vector pCR2.1 and the sequences of the inserts determined using primer pairs R16F2n/R16R2 (1250 bp) and $\mathrm{fU} 5 / \mathrm{rU} 3$ (890 bp). Clones from the 8 symptomatic MRD samples that were tested were all identical. Comparisons of these $16 \mathrm{~S}$ rRNA gene sequences of CYD to other phytoplasma $16 \mathrm{~S}$ rDNA sequences reported in Gen Bank, using the tool BLAST revealed that CYD belongs to the 'Candidatus phytoplasma cynodontis' group (16SrXIV) with $99 \%$ homology to the rRNA gene sequence of bermuda grass whiteleaf phytoplasma from Thailand (AF248961) and Malaysia (EU294011), members of the 16SrXIV. Phylogenetic analysis confirmed this classification (Fig. 3). The CYD phytoplasma rRNA gene sequences obtained in this study from MRD coconuts were deposited in the Gen Bank database under accession numbers EU328159.

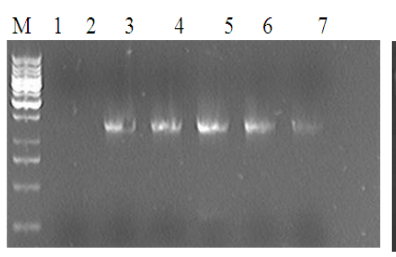

(a)

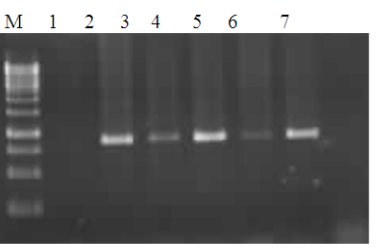

(b)
Fig. 1: (a): Amplification of CYD and other phytoplasma rRNA gene products with nested PCR primers R16F2n/R16R2. Lanes (M) 1 kb DNA ladder; (1) Healthy coconut palm $(2,3)$ Coconut yellow decline infected sample: (4) Bermuda grass white leaf: (5) Aster yellows: (6) Cape St Paul wilt: (7) water control; (b): Amplification of CYD and other phytoplasma rRNA gene products with nested PCR primers fU5/rU3. Lanes (M) $1 \mathrm{~kb}$ DNA ladder: (1) healthy coconut palm (trunk sample): $(2,3)$ Coconut yellow decline infected sample: (4) Bermudagrass white leaf: (5) Cape St Paul wilt: (6) Aster yellows: (7) Water control

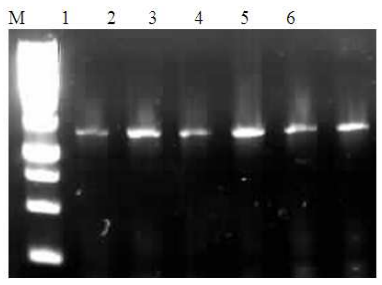

Fig. 2: Amplification of PCR products with nested PCR primers R16F2n/R16R2 from healthy MRD coconut samples. Lanes (M) $1 \mathrm{~kb}$ DNA ladder: (1-3) Midribs of spear leaf samples, (46) inflorescence samples 


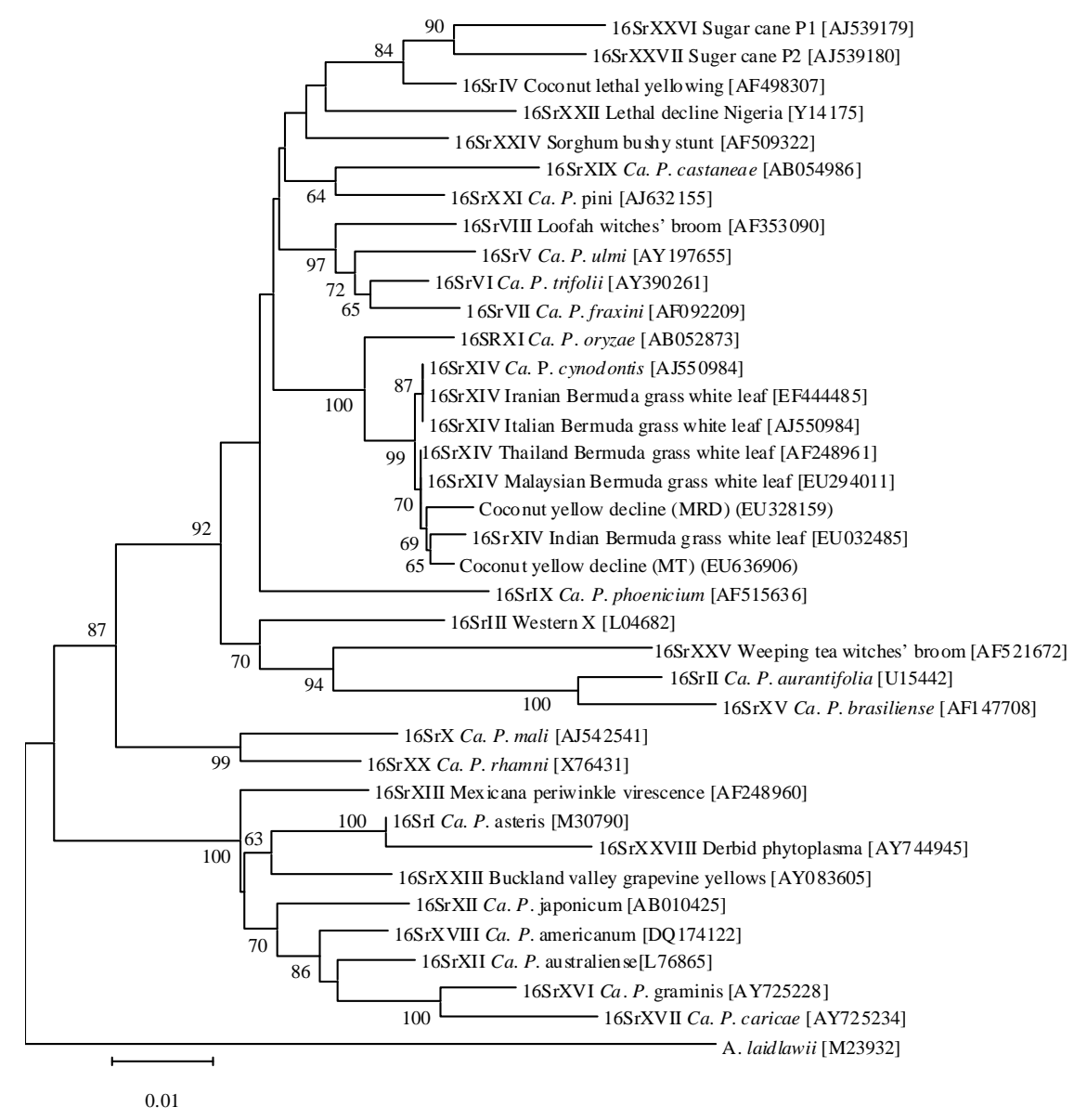

Fig. 3: Dendrograms, constructed by the Neighbor-Joining method, showing the phylogenetic relationships between the Malaysian coconut yellow decline phytoplasmas with 36 phytoplasmas and A. laidlawii as out group constructed based on 16S rRNA gene sequences. 16Sr groupings are based on the classification system of Wei et al. ${ }^{[53]}$. Gen Bank accession numbers for sequences obtained as part of this project along with previously published sequences are shown in Table 1 along side the names of the phytoplasmas. Bootstrap values greater than 50\% (expressed as percentages of 1000 replications) are shown and branch lengths are proportional to the number of inferred character state transformations. Bar substitutions per base

In addition to these phytoplasma sequences, the PCR products from spear leaves and inflorescences from symptomatic and asymptomatic MRD palms were also cloned and sequenced and alignments showed that these were clearly not of phytoplasma origin. Sequences from the R16F2n/R16R2 amplified fragments cloned from the 6 spear leaf and 2 inflorescence $1.3 \mathrm{~kb}$ samples from MRD palms showed $>99 \%$ similarity to $16 \mathrm{~S}$ rRNA gene sequence from the chloroplast of Elaeis oleifera with accession no. EU016925 $5^{[18]}$. There is no record in the database of the chloroplast 16S rRNA gene from coconuts, but it is presumed that it is the coconut chloroplast rRNA gene that has been amplified in these spear leaf samples. This 16S rRNA gene sequence which is presumed to come from the chloroplast of Cocos nucifera has been deposited at Gen Bank under accession number EU717157.

Comparison between the sequences of $\mathrm{R} 16 \mathrm{~F} 2 \mathrm{n} / \mathrm{R} 16 \mathrm{R} 21250 \mathrm{bp}$ products derived from the 5 symptomatic MRD inflorescence samples and the Gen Bank database indicated $>99 \%$ similarity with the 16S rRNA gene sequences from Bacillus spp. and $B$. megaterium. This presumably indicates the presence of these bacteria in the inflorescences and that the primers are not specific. To determine whether RFLP analysis could be used to distinguish between the R16F2n/R16R2 Bacillus PCR product that obtained from the CYD phytoplasma, cloned samples were digested 


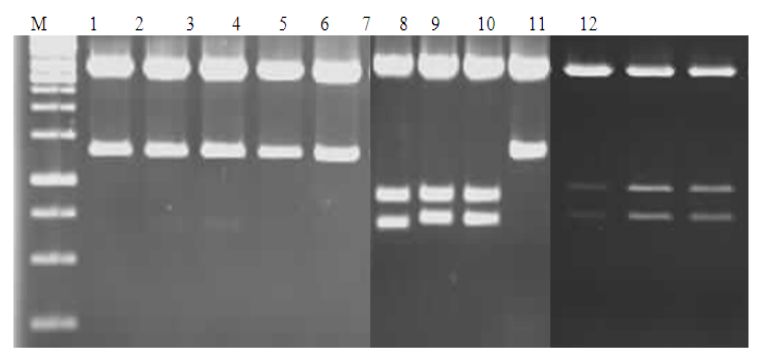

Fig. 4: RFLP analysis using EcoRI from cloned $\mathrm{R} 16 \mathrm{~F} 2 \mathrm{n} / \mathrm{R} 16 \mathrm{R} 2 \mathrm{PCR}$ samples in the pCR2.1 vector. Lanes (M) $1 \mathrm{~kb}$ DNA ladder: (1-5) chloroplast rDNA from spear leaves: (6-8) Bacillus rDNA from inflorescences: (9) chloroplast rDNA from an inflorescence; (1012) CYD phytoplasma rDNA from trunk borings. The large band of approx $4 \mathrm{~kb}$ is the pCR2.1 plasmid DNA and the smaller bands are from the rDNA PCR products

with $E c o$ RI. This enzyme was chosen because it had sites flanking the inserts but no other sites within the vector sequence, so the plasmid derived DNA could be separated from the insert DNA. Results in Fig. 4 show that there is a single EcoRI site in both the CYD phytoplasma and the Bacillus PCR product which gives rise to similar sized fragments, whilst there is no EcoRI site in the chloroplast DNA.

Virtual RFLP analysis: When nested-PCR products $(1.2 \mathrm{~kb})$ resulting from reamplification of primary $\mathrm{P} 1 / \mathrm{P} 7$ products by $\mathrm{F} 2 \mathrm{n} / \mathrm{R} 2$ were analysed by digestion with AluI, HhaI, HinfI, Sau3AI (MboI), MseI, RsaI and TaqI restriction endonucleases respectively, collective virtual RFLP patterns of CYD isolates from MRD ecotype were identical and belong to the 16SrXIV group (Fig. 5).

The virtual RFLP patterns of CYD phytoplasma isolates were very similar to Bermuda grass white leaf phytoplasma with all of these restriction endonucleases, Therefore, CYD phytoplasma strains was identified as a member of the Bermuda grass white leaf group (16Sr XIV). Furthermore, HinfI, MboI, RsaI and TaqI digests revealed similar patterns CYD phytoplasma strains to Ca. P. Oryzae (16SrXI). Whereas, AluI, HhaI, HinfI, Sau3AI (MboI), MseI, RsaI and TaqI digests indicated profiles differentiating CYD phytoplasma strains from coconut lethal yellowing (16SrIV) and lethal decline (16SrXXII).
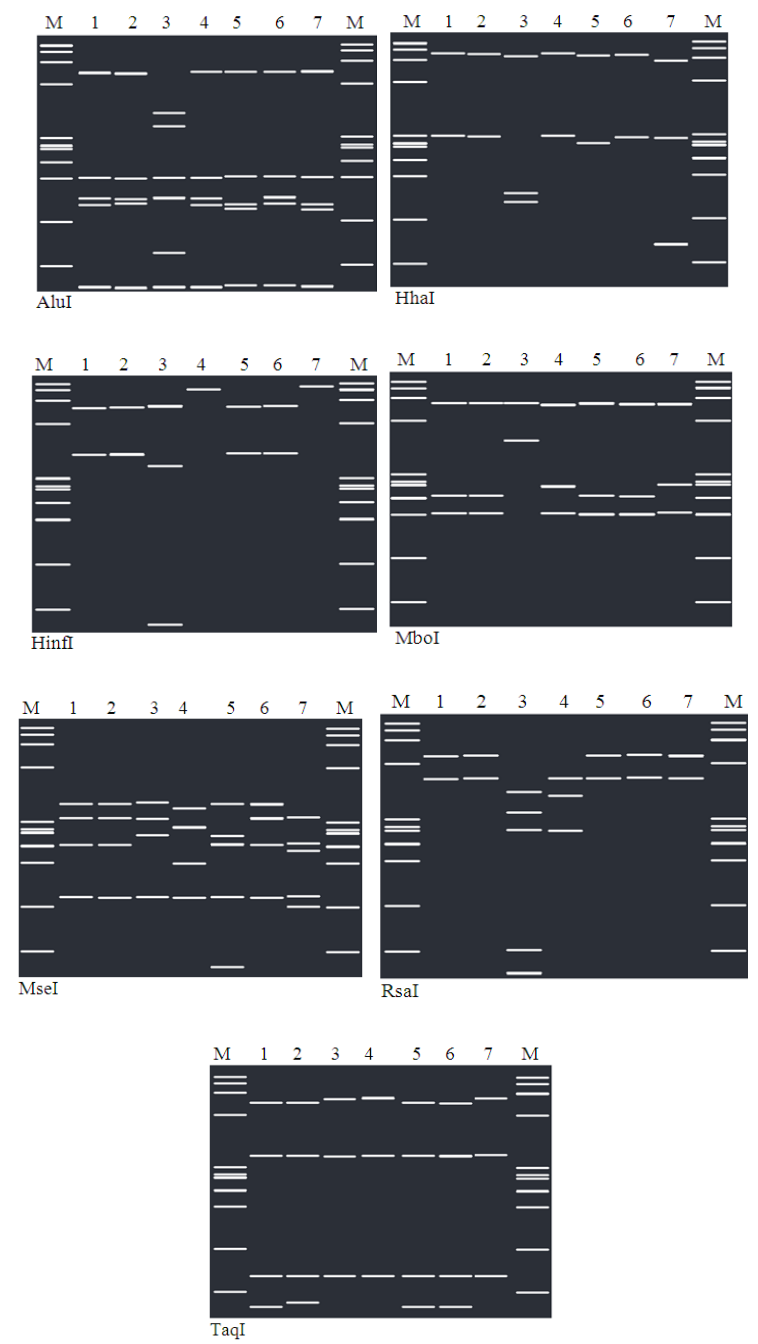

Fig. 5: Virtual RFLP analysis with AluI, HhaI, HinfI, Sau3AI (MboI), MseI, RsaI and TaqI restriction enzymes. Lanes (1): CYD from MRD ecotype (EU328159) (2): CYD from MT ecotype ((EU636906) (3): Ca. P. Asteris (16SrI) [M30790] (4): Coconut lethal yellowing (16SrIV) [AF498307] (5): Ca. P. oryzae (16SRXI) [AB052873] (6): Ca. P. cynodontis (16SrXIV) [AJ550984] (7): Lethal decline Nigeria (16SrXXII) [Y14175]. M: phX174DNA-HaeIII Digest DNA MW-marker

\section{DISCUSSION}

Results from PCR analysis confirmed the presence of a phytoplasma, but showed that the CYD phytoplasma is different from those that infect coconut in other parts of the world even though the symptoms 
are very similar. Coconut palms are known to be susceptible to the lethal yellowing (16SrIV) group phytoplasmas around the world. Lethal yellowing in the USA $^{[12]}$, Lethal Disease (LD) in Tanzania ${ }^{[44]}$, Cape St. Paul Wilt (CSPW) in Ghana ${ }^{[19,37]}$, Kaincope disease in $\operatorname{Tog}_{0}{ }^{[36]}$, Kribi disease in Cameroon ${ }^{[8]}$ and Awka or bronze leaf wilt (LDN) in Nigeria ${ }^{[9]}$ are all classified as $16 \mathrm{SrIV}$ phytoplasmas and give similar symptoms of premature fruit drop, floral necrosis leaf discoloration and decline. Subgroup 16SrIV-A phytoplasmas are associated with Lethal Yellowing (LY) of coconut and other palm species in the Americas ${ }^{[13]}$ whereas phytoplasmas that induce symptoms similar to LY on coconut in Africa are referred to by other names to reflect strain differences that have previously been identified through 16S rRNA gene analysis. Recently, Wei et al ${ }^{[53]}$ have allocated the Nigerian coconut Lethal Decline Group (LDN) to a distinct 16Sr group, 16SrXXII-A and this has been confirmed by the work of Hodgetts et al. ${ }^{[17]}$, who showed a high degree of divergence between the different coconut phytoplasmas based on the secA gene which supported their separation into at least three distinct 'Ca. Phytoplasma' species that reflect the geographical origins of the strains.

The 16SrXIV phytoplasma found on coconut in Malaysia is from a very different phylogenetic group to the lethal yellowing-like phytoplasmas and is more closely related to the phytoplasmas found in Bermuda grass in Thailand and Malaysia. This situation is similar to the findings for the Kalimantan Wilt (KW) disease of coconuts in Indonesia which belongs to the $16 \mathrm{SrXI}$ rice yellow dwarf phytoplasma group ${ }^{[52]}$. Rice and sugarcane in Indonesia is known to be infected with 16SrXI phytoplasmas such as rice yellow dwarf, sugarcane white leaf, sugarcane grassy shoot and Ramu stunt disease and sugarcane is grown in gardens in the area affected by $\mathrm{KW}$ disease. It is therefore possible that these phytoplasmas in Indonesia and Malaysia are ones that are adapted to grasses and use coconut as an alternate host, possibly because their vectors, which have not as yet been identified, are able to feed on coconut and these grasses. By contrast, the 16SrIV lethal yellowing-like phytoplasmas seem to be much more specific to coconut and closely related palm species. This may also explain why some of the symptoms associated with the Malaysian and Indonesian coconut phytoplasmas are distinct and different from those that occur in Africa and the Americas.

Two unexpected results were obtained during this study. Firstly, the universal phytoplasma primer pair, R16F2n/R16R2 amplified the 16S rRNA gene from coconut chloroplast derived from spear leaf and inflorescence samples of some asymptomatic coconut palms. These results indicate that $\mathrm{R} 16 \mathrm{~F} 2 \mathrm{n} / \mathrm{R} 16 \mathrm{R} 2$ can amplify plant DNA. Secondly, Bacillus spp., were amplified with these primers from the inflorescences of some asymptomatic coconut palms. The Bacillus and chloroplast rDNA sequence sizes were similar to the phytoplasma rDNA sequence size. Bacillus megaterium has previously been isolated from the trunk samples of date palms (Phoenix canariensis Chabaud) affected by the lethal decline phytoplasma using universal phytoplasma primer pair (P1/P7) in Texas ${ }^{[14]}$. This clearly indicates that care needs to be taken when using these universal phytoplasma primers on samples that contain other Gram positive bacteria, especially as RFLP analysis with some enzymes such as EcoRI can give similar sized products. Other restriction enzymes could be used to discriminate between Bacillus and phytoplasma and in addition, more specific universal phytoplasma primers are currently being developed $^{[16,17,31]}$ and it may be that these will be more suitable for diagnostics from samples such as coconuts which appear to harbor other Gram-positive bacteria in significant populations particularly on the spear leaves and inflorescences.

\section{CONCLUSION}

The results presented herein reveal the molecular characterization of phytoplasma associated with CYD disease of coconut palm. The results presented show that sequencing is a reliable method for the detection, identification and classification of CYD phytoplasmal disease. In order to achieve a basic understanding of phytoplasma pathogenesis and phytoplasma control strategies, sequencing is the powerful and reliable method to identify and classify the phytoplasmas.

\section{ACKNOWLEDGEMENT}

We gratefully acknowledge Mr. Hamdan Ibrahim, Mr. Mohaimi, Mr. Yusoff Mohd. Yassin and Mrs. Junaina Jaafar for their technical assistance. Financial support for this work was provided by FRGS (Project Grant 05-10-7-373FR).

\section{REFERENCES}

1. Ahrens, U. and E. Seemüller, 1992. Detection of DNA of plant pathogenic mycoplasmalike organisms by a polymerase chain reaction that amplifies a sequence of the 16S rRNA gene. Phytopathology, 82: 828-832. http://cat.inist.fr/?aModele $=$ afficheN\&cpsidt $=5458$ 891 
2. Altschul, S.F., W. Gush, W. Miller, W. Myers and D.J. Lipman, 1990. Basic local alignment search tool. J. Mol. Biol., 215: 403-410. http://www.ncbi.nlm.nih.gov/pubmed/2231712

3. Arocha, Y., M. Lopez, B. Pinol, M. Fernandez and P. Jones, 2005. Candidatus Phytoplasma graminis and Candidatus Phytoplasma caricae two novel phytoplasmas associated with diseases of sugarcane, weeds and papaya in Cuba. Int. J. Syst. Evolut. Microbiol., 55: 2451-2463. http://www.ncbi.nlm.nih.gov/pubmed/16280510

4. Blanche, K.R., L.T. Tran-Nguyen and K.S. Gibb, 2003. Detection, identification and significance of phytoplasmas in grasses in northern Australia. Plant Pathol., 52: 505-512. http://cat.inist.fr/?aModele $=$ afficheN\&cpsidt $=15000020$

5. Constable, F.E., J.R. Whiting, K.S. Gibb and R.H. Symons, 2002. A new grapevine yellows phytoplasma from the Buckland valley of Victoria Australia. Vitis, 41: 147-153. http://cat.inist.fr/?aModele=afficheN\&cpsidt=13946907

6. Davis, R.E., E.L. Dally, D.E. Gundersen, I.M. Lee and N. Habili, 1997. Candidatus phytoplasma australiense a new phytoplasma taxon associated with Australian grapevine yellows. Int. J. Syst. Bacteriol., 47: 262-269. http://www.ncbi.nlm.nih.gov/pubmed/9103609

7. Deng, S. and C. Hiruki, 1991. Amplification of 16S rRNA genes from culturable and non culturable mollicutes. J. Microbiol. Methods, 14: 53-61. DOI: 10.1016/0167-7012(91)90007-D

8. Dollet, M., J. Giannotti, J.L. Renard and S.K. Ghosh, 1977. Study of lethal yellowing of coconuts in cameroon: Kribi disease. Observat. Mycoplasmalike Org. Oleagineux, 32: 317-322. http://www.cababstractsplus.org/abstracts/Abstract. aspx?AcNo=19776718394

9. Ekpo, E.N. and E.E. Ojomo, 1990. The spread of lethal coconut diseases in West Africa: Incidence of Awka disease (or bronze leaf wilt) in the Ishan area of Bendel State of Nigeria. Principes, 34: 143-146.

10. Griffiths, H.M., W.A. Sinclair, C.D. Smart and R.E. Davis, 1999. The phytoplasma associated with ash yellows and lilac witches-broom: Candidatus phytoplasma fraxini. Int. J. Syst. Bacteriol., 49: 1605-1614.

http://cat.inist.fr/?aModele=afficheN\&cpsidt=1189139

11. Gundersen, D.E. and I.M. Lee, 1996. Ultrasensitive detection of phytoplasmas by nested-PCR assays using two universal primer pairs. Phytopathol. Mediterranea, 35: 144-151. http://direct.bl.uk/bld/PlaceOrder.do?UIN=018498 $390 \&$ ETOC $=$ RN\& from $=$ searchengine
12. Harrison, N.A., C.M. Bourne, R.L. Cox, J.H. Tsai and P.A. Richardson, 1992. DNA probes for detection of mycoplasmalike organisms associated with lethal yellowing disease of palms in Florida. Phytopathology, 82: 216-224. http://cat.inist.fr/?aModele $=$ afficheN\&cpsidt=5099353

13. Harrison, N.A., W. Myrie, P. Jones, M.L. Carpio and C. Oropeza, 2002. 16S rRNA interoperon sequence heterogeneity distinguishes strain populations of the palm lethal yellowing phytoplasma in the Caribbean region. Annals Applied Biol., 141: 183-193. http://cat.inist.fr/?aModele $=$ afficheN\&cpsidt=13946846

14. Harrison, N.A., M. Womack and M.L. Carpio, 2002. Detection and characterization of a lethal yellowing (16SrIV) group phytoplasma in Canary Island date palms affected by lethal decline in Texas. Plant Dis., 86: 676-681. http://cat.inist.fr/?aModele $=$ afficheN\&cpsidt $=13678922$

15. Hiruki, C. and K. Wang, 2004. Clover proliferation phytoplasma: Candidatus Phytoplasma trifolii. Int. J. Syst. Evol. Microbiol., 54: 1349-1353. http://www.ncbi.nlm.nih.gov/pubmed/15280313

16. Hodgetts, J., T. Ball, N. Boonham, R. Mumford and M. Dickinson, 2007. Use of terminal restriction fragment length polymorphism ( $\mathrm{T}$ RFLP) for identification of phytoplasmas in plants. Plant Pathol., 56: 357-365. http://cat.inist.fr/?aModele $=$ afficheN\&cpsidt $=18734564$

17. Hodgetts, J., N. Boonham, R. Mumford, N. Harrison and M. Dickinson, 2008. Phytoplasma phylogenetics based on analysis of $\sec \mathrm{A}$ and $23 \mathrm{~S}$ rRNA gene sequences for improved resolution of candidate species of Candidatus Phytoplasma. Int. J. Syst. Evol. Microbiol., 58: 1826-1837. http://www.ncbi.nlm.nih.gov/pubmed/18676464

18. Jansen, R.K., Z. Cai, L.A. Raubeson, H. Daniell and J.L. Boore et al., 2007. Analysis of 81 genes from 64 plastid genomes resolves relationships in angiosperms and identifies genome-scale evolutionary patterns. Proc. Nat. Acad. Sci. USA., 104: 19369-19374.

http://www.pnas.org/content/104/49/19369.abstract

19. Johnson, C.G. and H.C. Harries, 1976. A survey of cape St. paul wilt in west Africa. Ghana J. Agric. Sci., 9: 125-129.

http://kbd.kew.org/kbd/detailedresult.do?id=48105

20. Jung, H.Y., T. Sawayanagi, S. Kakizawa, H. Nishigawa and S. Namba et al., 2002. Candidatus Phytoplasma castaneae, a novel phytoplasma taxon associated with chestnut witches' broom disease. Int. J. Syst. Evol. Microbiol., 52: 1543-1549. http://www.ncbi.nlm.nih.gov/pubmed/12361256 
21. Jung, H.Y., T. Sawayanagi, P. Wongkaew, S. Kakizawa and S. Namba et al., 2003. Candidatus Phytoplasma oryzae, a novel phytoplasma taxon associated with rice yellow dwarf disease. Int. J. Syst. Evolut. Microbiol., 53: 1925-1929. http://www.ncbi.nlm.nih.gov/pubmed/14657124

22. Kumar, S., K. Tamura and M. Nei, 2004. MEGA3: Integrated software for molecular evolutionary genetics analysis and sequence alignment. Brief. Bioinform., 5: 150-163. http://www.ncbi.nlm.nih.gov/pubmed/15260895

23. Lee, I.M. and R.E. Davis, 1992. Mycoplasmas which Infect Insects and Plants. In: Mycoplasmas: Molecular Biology and Pathogenesis, Maniloff, J., R.N. McElmansey, L.R. Finch and J.B. Baseman (Eds.). American Society for Microbiology, Washington DC., ISBN: 1555810500, pp: 609.

24. Lee, I.M., K.D. Bottner, G. Secor and V. RiveraVaras, 2006. Candidatus Phytoplasma americanum' a phytoplasma associated with a potato purple top wilt disease complex. Int. J. Syst. Evolut. Microbiol., 56: 1593-1597. http://www.ncbi.nlm.nih.gov/pubmed/16825635

25. Lee, I.M., D.E. Gundersen-Rindal, R.E. Davis, K.D. Bottner and E. Seemüller, 2004. Candidatus Phytoplasma asteris, a novel phytoplasma taxon associated with aster yellows and related diseases. Int. J. Syst. Evolut. Microbiol., 54: 1037-1048. http://cat.inist.fr/?aModele $=$ afficheN\&cpsidt $=15975795$

26. Lee, I.M., R.W. Hammond, R.E. Davis and D.E. Gundersen-Rindal, 1993. Universal amplification and analysis of pathogen $16 \mathrm{~S}$ rDNA for classification and identification of mycoplasmalike organisms. Phytopathology, 83: 834-842. http://cat.inist.fr/?aModele $=$ afficheN\&cpsidt $=4881299$

27. Lee, I.M., M. Martini, C. Marcone and S.F. Zhu, 2004. Classification of phytoplasma strains in the elm yellows group (16SrV) and proposal of Candidatus Phytoplasma ulmi for the phytoplasma associated with elm yellows. Int. J. Syst. Evolut. Microbiol., 54: 337-347.

http://www.ncbi.nlm.nih.gov/pubmed/15023941

28. Lorenz, K.H., B. Schneider, U. Ahrens and E. Seemüller, 1995. Detection of the apple proliferation and pear decline phytoplasmas by PCR amplification of ribosomal and nonribosomal DNA. Phytopathology, 85: 771-776.

http://cat.inist.fr/?aModele $=$ afficheN\&cpsidt $=3634039$

29. Marcone, C., K.S. Gibb, C. Streten and B. Schneider, 2004. Candidatus Phytoplasma spartii, Candidatus Phytoplasma rhamni and Candidatus phytoplasma allocasuarinae, respectively associated with spartium witches'-broom, buckthorn witches'broom and allocasuarina yellows disease. Int. J. Syst. Evol. Microbiol., 54: 1025-1029. http://www.ncbi.nlm.nih.gov/pubmed/15280265
30. Marcone, C., B. Schneider and E. Seemuller, 2004. Candidatus Phytoplasma cynodontis, the phytoplasma associated with Bermuda grass white leaf disease. Int. J. Syst. Evolut. Microbiol., 54: 1077-1082. http://cat.inist.fr/?aModele $=$ afficheN\&cpsidt $=15975800$

31. Martini, M., I.M. Lee, K.D. Bottner, Y. Zhao and R. Osler et al., 2007. Ribosomal protein genebased phylogeny for finer differentiation and classification of phytoplasmas. Int. J. Syst. Evolut. Microbiol., 57: 2037-2051. http://www.ncbi.nlm.nih.gov/pubmed/17766869

32. Menon, K.P.V. and K.M. Pandalay, 1958. The coconut palm. A monograph. Indian Central Coconut Committe. India. http://indianmedicine.eldoc.ub.rug.nl/root/M/66839/

33. Montano, H.G., R.E. Davis, E.L. Dally, S. Hogenhout and S.T. Brioso et al., 2001. Candidatus Phytoplasma brasiliense, a new phytoplasma taxon associated with hibiscus witches' broom disease. Int. J. Syst. Evolut. Bacteriol., 51: 1109-1118. http://www.ncbi.nlm.nih.gov/pubmed/11411679

34. Nejat, N., K. Sijam, S.N.A. Abdullah, G. Vadamalai and M. Dickinson, 2008. First report of a 16SrXIV, Candidatus phytoplasma cynodontis' group phytoplasma associated with coconut yellow decline in Malaysia. New Disease Reports 17. http://www.bspp.org.uk/publications/new-diseasereports/july2008/2008-24.asp

35. Nejat, N., K. Sijam, S.N.A. Abdullah, G. Vadamalai and M. Dickinson, 2009. First report of a 16SrXIV, 'Candidatus phytoplasma cynodontis' group phytoplasma associated with coconut yellow decline in Malaysia. Plant Pathol., 58: 389.

36. Nienhaus, F. and K.G. Steinert, 1976. Mycoplasmalike organisms associated with kaincope disease of coconut palm in Togo. Plant Dis. Rep., 60: 1000-1002.

37. Nipah, J.O., P. Jones and M.J. Dickinson, 2007. Detection of lethal yellowing phytoplasma in embryos from coconut palms infected with Cape St Paul wilt disease in Ghana. Plant Pathol., 56: 777-784. http://cat.inist.fr/?aModele $=$ afficheN\&cpsidt $=1906$ 5740

38. Parthasarathy, M.V., 1974. Mycoplasma-like organisms associated with lethal yellowing disease of palms. Phytopathology, 64: 667-674. DOI: 10.1111/j.1439-0434.1974.tb02810.x

39. Plavsic-Banjac, B., P. Hunt and K. Maramorosch, 1972. Mycoplasma-like bodies associated with lethal yellowing disease of coconut palms. Phytopathology, 62: 298-299.

http://kbd.kew.org/kbd/detailedresult.do?id=41861 
40. Robert, M.L. and V.D. Zizumbo, 1990. La problematica del amarillamiento letal del cocotero en Mexico. Yucatan, Mexico, CICY.

41. Sawayanagi, T., N. Horikoshi, T. Kanehira, M. Shinohara, A. Bertaccini and S. Namba et al., 1999. Candidatus phytoplasma japonicum, a new phytoplasma taxon associated with Japanese hydrangea phyllody. Int. J. Syst. Bacteriol., 49: 1275-1285.

http://www.ncbi.nlm.nih.gov/pubmed/10425791

42. Schneider, B., E. Seemüller, C.D. Smart and B.C. Kirkpatrick, 1995. Phylogenetic Classification of Plant Pathogenic Mycoplasma-Like Organisms or Phytoplasmas. In: Molecular and Diagnostic Procedures in Mycoplasmology, Razin, S. and G.J. Tully (Eds.). Academic Press, New York, USA., pp: 369-380. ISBN: 978-0-12-583805-4

43. Schneider, B., E. Torres, M.P. Martin, M. Schroder and E. Seemuller, 2005. Candidatus Phytoplasma pini, a novel taxon from Pinus silvestris and Pinus halepensis. Int. J. Syst. Evolut. Microbiol. 55: 303-307. http://www.ncbi.nlm.nih.gov/pubmed/15653891?d opt=Abstract

44. Schuiling, M., D.A. Kaiza and A. Mpunami, 1992a. Lethal disease of coconut palm in Tanzania II: history, distribution and epidemiology. Oléagineux, 47: 516-521.

45. Seemuller, E. and B. Schneider, 2004. Candidatus phytoplasma mali, Candidatus phytoplasma pyri and Candidatus phytoplasma prunorum, the causal agents of apple proliferation, pear decline and European stone fruit yellows, respectively. Int. J. Syst. Evolut. Microbiol., 54: 1217-1226. http://cat.inist.fr/?aModele $=$ afficheN\&cpsidt $=1597$ 5823

46. Seemüller, E.C., U. Marcone, A. Lauer, A. Ragozzino and M. Goschl, 1998. Current status of molecular classification of the phytoplasma. J. Plant Pathol., 80: 3-26.

http://www.sipav.org/main/jpp/volumes/0198/0198 01.pdf

47. Snehi, S.K., M.S. Khan, S.K. Raj, S. Mall, M. Singh and G.P. Rao, 2008. Molecular identification of Candidatus phytoplasma cynodontis associated with bermuda grass white leaf disease in India. Plant Pathol., 57: 770-770. DOI: 10.1111/j.13653059.2008.01853.x

48. Srinivisulu, B. and D.V. Raghava Rao, 2007. Coconut Diseases. 1st Edn., Lucknow, International Book Distributing Co., ISBN: 818189-188-0, pp: 114.
49. Thompson, J., D. Higgins and T.J. Gibson, 1994. CLUSTAL W: Improving the sensitivity of progressive multiple sequence alignment through sequence weighting, position-specific gap penalties and weight matrix choice. Nucleic Acids Res., 22: 4673-4680. http://www.ncbi.nlm.nih.gov/pubmed/7984417

50. Tymon, A.M., P. Jones and N.A. Harrison, 1998. Phylogenetic relationships of coconut phytoplasmas and the development of specific oligonucleotide PCR primers. Ann. Applied Biol., 132: 437-452.

http://cat.inist.fr/?aModele $=$ afficheN\&cpsidt=2395 464

51. Verdin, E., P. Salar, J.L. Danet, E. Choueiri and F. Jreijiri et al., 2003. Candidatus phytoplasma phoenicium sp., nov., a novel phytoplasma associated with an emerging lethal disease of almond trees in Lebanon and Iran. Int. J. Syst. Evolut. Microbiol., 53: 833-838. http://www.ncbi.nlm.nih.gov/pubmed/12807209

52. Warokka, J.S., P. Jones and M.J. Dickinson, 2006. Detection of phytoplasma associated with Kalimantan wilt disease of coconut by the polymerase chain reaction. J. Littri, 12: 154-160.

53. Wei, W., R.E. Davis, I.M. Lee and Y. Zhao, 2007. Computer-simulated RFLP analysis of $16 \mathrm{~S}$ rRNA genes: Identification of ten new phytoplasma groups. Int. J. Syst. Evolut. Microbiol., 57: 1855-1867. http://www.ncbi.nlm.nih.gov/pubmed/17684271

54. Weisburg, W.G., J.G. Tully, D.L. Rose, J.P. Petzel and C.R. Woese et al., 1989. A phylogenetic analysis of the mycoplasmas: Basis for their classification. J. Bacteriol., 171: 6455-6467. http://www.ncbi.nlm.nih.gov/pubmed/2592342

55. Zhang, Y.P., J.K. Uyemoto and B.C. Kirkpatrick, 1998. A small-scale procedure for extracting nucleic acids from woody plants infected with various phytopathogens for PCR assay. J. Virol. Methods, 71: 45-50. http://www.ncbi.nlm.nih.gov/pubmed/9628220

56. Zreik, L., P. Carle, J.M. Bove and M. Garnier, 1995. Characterization of the mycoplasmalike organism associated with witches'-broom disease of lime and proposition of a Candidatus taxon for the organism, Candidatus phytoplasma aurantifolia. Int. J. Syst. Bacteriol., 45: 449-453. http://www.ncbi.nlm.nih.gov/pubmed/8590671 